\section{PROF. J. F. W. VON BEZOI,D.}

$\mathrm{I} T$ is with deep regret that we record the death on Sundav last, February 17 , of Prof. Wilhelm von Bezold, director of the Prussian Meteorological Institute.

Von Bezold was born at Munich in June, 1837 , and was admitted to the degree of $\mathrm{Ph}$. D. at Göttingen in I860. Thence he returned to Munich as privatdocent in $186 \mathrm{I}$, became extraordinary professor in the University in 1866 , and ordinary professor at the Polytechnic in 1868 . In 1878 he undertook the organisation of the Bavarian meteorological service as director of the central meteorological station, and remained in charge of the service until I885, when he was called to Berlin as professor of meteorology in the University, and director of the Meteorological Institute, which was reorganised by him.

The Institute included not only the central establishment in Berlin, which formed the headquarters of the branch in charge of Prof. Hellmann for dealing with the climatology and rainfall of the Prussiau kingdom, but also the meteorological and magnetic observatories at Potsdam, in connection with which the names of Sprung, Eschenhagen, and A. Schmidt are so well known, and the aëronautical section at Tegel, which was brought into existence and developed as a branch of the Institute under Prof. Assmann. A year and a half ago the work of the latter institution was transferred to the new and independent establishment at Lindenberg.

In the course of his long and distinguished scientific career von Bezold's activity ranged over a wide field. His writings include papers on colour vision and the retina, and the dust figures of electrical discharge; but he is best known for his contributions to meteorology as the physics of the atmosphere, the aspect of the subject which he found most attractive, and to the theory of terrestrial magnetism. A volume of his collected papers on these subjects was issued as recently as October, 1906, by Vieweg and Son. It includes the papers on the thermodynamics of the atmosphere, contributed to the Berlin Academy, which are the classical memoirs upon that section of meteorology. The last paper in the collection contains his proposal for testing Gauss's theory of terrestrial magnetism by measurements along a complete parallel of latitude. This was before the Association of Academies in London in 1904, when von Bezold was one of the representatives of the Berlin Academy.

All who had the advantage of being associated with him in international work will miss his kindly presence and scientific enthusiasm, as well as his sympathetic and cautious counsel.

\section{PROF. N.A. MENSCHUTKIN.}

PROF. NICOLAI ALEXANDROVICH MENSCHUTKIN, who died on February 5, was born in St. Petersburg on October 24, I 842 . After finishing his studies at the St. Petersburg University, he went abroad and worked in the laboratories of Schtreker in Tübingen, Würtz in Paris, and Kolbe in Marburg. On his return to St. Petersburg in 1865 , he read his dissertation for the degree of Master of Chemistry on "The Hydrogen of Phosphorous Acid and. its Incapacity to be replaced by Metals." In 1867 he began to lecture on chemistry at the St. Petersburg University. $\mathrm{He}$ also gave special lectures on organic chemistry, and was head of the analytical laboratory. In 1885 he left the analytical department and devoted himself entirely to teaching organic chemistry. His doctor's dissertation was on "The Synthesis and Properties of Hydrocarbons." In the seventies of last century he was secretary, and in the eighties rector, of the Physicu-mathematical Faculty. In recent years he left the University and lectured at the Polytechnic Institute of St. Petersburg.

Menschutkin devoted his spare time to the Physicochemical Society, the Journal of which he edited. $\mathrm{He}$ was vice-president of the Students' Aid Society, and, being a fine musician, he organised the students' choir and orchestra.

His first researches were on the inorganic acids, but he subsequently devoted himself almost exclusively to organic chemistry. In the 'seventies he did some good work in the province of physical chemistry and in the mechanics of chemistry. His researches on the influence of isomerism of alcohols and acids on the formation of composite ethers were published in the Records of the St. Petersburg Imperial Academy in 1877 , and he was awarded the Sokoloff medal for this work. This was his first fundamental work, and it marked an epoch in the history of Russian chemistry. Prof. Menschutkin supplemented these researches by further work on the same subject in $\mathrm{I} 88 \mathrm{I}$. His researches on etherification from 1877 to 1882 brought many important additions to that branch of organic chemistry. In 1898 , I900, and 1902 he was occupied in investigating the influence of carbon chains on the velocity of reaction and decomposition of carbon compounds. His last important research was on the velocity of chemical change in the polymethylene series, which was translated into English and published in the Journal of the Chemical Society. A paper on the "Influence of Catalysts on the Formation of Anilides" almost closes his scientific career.

His "Lectures on Organic Chemistry" passed through many editions. His "Analytical Chemistry" became the text-book for all the Russian universities and technical schools. In his preface to the sixth edition, which has been translated into English and German, Prof. Menschutkin claims that analyticat chemistry should form the basis for the study of organic and physical chemistry. Prof. Menschutkin, unlike his contemporary Prof. Mendeléeff, was a wonderful manipulator in the laboratory, and this was partly the secret of the precision of his results. Prof. Mendeléeff had the wider vision of the science, Prof. Menschutkin excelled in details. His earliest work was much influenced by his first teacher, Prof. Sokoloff.

\section{NOTES.}

It was announced in Sunday's Observer that the Government would shortly introduce a Bill dealing with the constitution of the proposed Imperial College of Applied Science at South Kensington, and the relation of the college to the University of London. We find, however, that this report is incorrect; though the scheme for the establishment of the college was outlined nearly four years ago, when Messrs. Wernher, Beit and Co. offered 500,00ol. towards the cost and the London County Council agreed to contribute $20,000 \mathrm{l}$. a year for maintenance, the matter is still in abevance. This delay, as we have remarked before, is both unfortunate and dangerous. The chief point at issue is whether the college shall form part of the University of London and be controlled by the Senate of the University, or whether it shall be an independent institution having a governing body of its own. While the relationship between the two institutions is being decided, there is no visible sign that the scheme is taking definite shape, and many men of science and leaders of industry are becoming impatient at the delay. The departmental committee on the Royal College of Science

NO. I 947 , VOL 75$]$ 